\title{
Challenges and Its Approaches to Bring Integration of Indonesian People
}

\author{
Ulung Napitu, Opan S. Suwartapradja ${ }^{2}$, Budi Radjab ${ }^{2}$, Junardi Harahap ${ }^{2}$ \\ ${ }^{1}$ Department of Historical of Education, Faculty of Teacher Training and Education, University of \\ Simalungun, Pematang Siantar, Indonesia \\ ${ }^{2}$ Postgraduate Program of Social and Political Science, University of Padjadjaran, Bandung, Indonesia \\ E-mail: ulungnapitu2018@gmail.com
}

\begin{abstract}
:
This paper deal with the challenges in and approaches to bringing about both and integration in multiethnic Indonesia's people life. Till now, some challenges in national integration are still found in forms of: SARA (ethnicity, religion, and inter-group)-based social conflicts, fake news (hoax), hate speeches (e.g. Saracen), radical movements, separatism movements, etc. These are due to inequality $n$ social-economic development, low awareness of some elements of the state, and allegedly discriminative practices. Overcoming the multi-dimension problems needs genuine commitment, hard work, allegiance to the Constitusion and Pancasila (Indonesia's ideological principles) as the state foundation, and awareness of the whole elements of the nation. To analyze deeply the phenomena relating to the callenges in and approaches to bringing about national integration, a library research method was used. Building on written sources of books, journals, newspapers and other prited media, the current paper could expectedly result in a valuable publication. The analysis performed in the present writing started by selecting, evaluating, and analyzing contents and the shynthezing the contents of different books and journals so as to draw conclusions. To secure the validity of the printed sources, the author out both external and internal critiques of the library sources used.
\end{abstract}

Keywords:

challenge; approach; integration; Indonesian nation

\section{Introduction}

The Unitary state of Repulic of Indonesia (NKRI), proclaimed on 17 Auguts 1945, was founde on a basis of ethnic diversity, not of ethnic uniformity. That Republic of Indonesia was established based on diversity is reflected in a slogan Bhineka Tuggal Ika (Unity in Diversity). As a depicyion of the diversity of ethnicities occupying Indonesia, the population of Indoneia, according to Central Bureau of Statistics data (BPS, 2018) consists of \pm 300 ethnicities, 1.340 races, and $\pm 265,015,000$ citizens spreading in $\pm 17,000$ islands. The ethnic, racial, religious, and group complexcities are a social challenge, for keeping harmony and the integration of nation. By integration is meant "assimilation and unification into an intact or complete unity." And by "nation" is meat as: (1) a group of national ethnicities/tribes; (2) having distinct characteristics: national aspirations, national cultures, and an integrated territory. National aspects may also be in forms of customs, tribes, colors, descendants, religions, cultures, territories, and so on. According to Kartodirdjo (1993), national integration begins with territorial and geopolitical integrations generated by transportation, navigation, and trade, leading in turn to more extensive and intensive economic, social, politic and cultural communications. In prehistoric times, a navigation network had been developed. Culminating in Sriwijaya and Majapahit eras, and instensified during the Netherland Indies era by military expeditions. Then, in NKRI era, it was strengthened by the existence of centralistic administration system through educational, military, and communicatioanl systems. 
Communication is the process of sending messages from one party to another through certain contexts such as intrapersonal communication, interpersonal or interpersonal communication, group communication or organizational communication and mass communication. When communication takes place in the context of group communication or organizational communication, it will have its own communication network or pattern (Hasbullah, 2018).

Referring to the description of the term, it can be concluded that national integrity is identical to the integrity of nation, defined as "a process of unifying or assimilating diverse social-cultural aspects into a territorial unity and establishing a natioanl identity (Suhady \& Sinaga, 2006). Given the so complex problems the nation is facing now, the government and all other national elements should work hard and cooperatively to resolve them in order to bring about a harmonious and peaceful social life, and hence national integration.

The current reformation, demanding democratization, freedom, equality, human rights, and openness, is a crucial moment for restructuring our life as a nation state for the better and to be more respected by others. The behaviors required to the purpose are honesty, opennes, and accountability of the government in building politics, law, socio-culture, security nd other relevant aspects. If the epproach applied is inappropriate, and socio-culture, security and social prosperity are neglected, various social vulnerabilities and horizontal and vertical conflicts in our national life will potentially be triggered.

Such condition should have not accored if a dialogue approach between and among religious communities were practiced. If the epproach were not not implemented under full consciousness, it would be impossible to bring about a harmonious life (Wahab, 2015; Suryana et al., 2015).

Responding to the diversity, the entire national elements should seek similarities in differences, insteda of differences in similarities. Such a harmony in life is decribed by Park, saying that social life is like a "small mosaic". That is, social communities do, while interacting with one another, not purge one another (Fischer, 1980). If this outlook were implemented in daily lives, differences in tribe, religion, race and inter-group would not turn into a threat. Instead, it may serve as a safety valve of social conflicts amid a community.

\section{Research Methods}

To figure out the challenges and the approaches used in establishing national integration, a qualitative method with a library research was used. A library research is one that uses the materials of library collections in forms of books, journals, and other printed sources without conducting a field research, as it is common for researches in general (Danim, 2002; Zed, 2008). Referring to this statement, the sources used were books, journals, and other libarray resources.

Library research is a method of collecting data by analyzing printed sources available in forms of books, journals, a dother relevants sources (Koentjaningrat, 1977; Creswell, 2014). Complementing the written sources, relevant documents were also used. The steps taken were collecting, selecting, evaluating, synthesizing, analyzing, and criticizing diverse documents (Bugin, 2008; Creswell, 2015). 
Based on the description above, writing the present papaer started by selecting books, journals, and other relevant literature, supplemented by documents. To secure the validity of the printed sources, the author carried out both external and internal critiques of the sources and documents used. That is, the printed sources connecting to challenges, the social vulnerabilities inducting national disintegration, and the approavhes applied for establishing national integration were chosen selectively, evaluated, compared, analyzed, and synthesized so as to draw conclusions.

\section{Discussion}

\subsection{Challenges in Realizning National Integration}

Pursuant to the 1945 constituion, article 28, freedoms of expression and of speech publiicly are protected by law. Moreover, articles 28, 29,30,31, and 34 of the constitution lay down citizens' basic rights to freedoms of speech orally and in writing, of religion, of civic defense, and of education and decent livelihood. Where these provisions are implemented consitently by the state, togethre with all elements of the nation, there would not be infringement of basic human rights. Basic humana rights are ones inherent to individuals a $\mathrm{s}$ human beings, and apply to each member of human beings regardless divisive factors such as: race, religion, color, caste, faith, gender, or nationality (Hass et all, 1998).

Indonesia is a legal state that strongly promotes legal philosophy to unite people in one frame of the nation, one unit, one language, and family principles, even though the follow-up of laws created is often a hybrid (Khalil, 2019). Since 1998, with progression of reformation movement, there has been a rise of euphoria of reformation in Indonesia. Some people perceive that the freedom of expression is a limitless one. The euphoria, on the onther side, brings about openness of information, thus democracy may develop in Indonesia with a multiple parties world because, since the reformation, Indonesia has come to be one of the most democratic states in the world, as indicated by the succesful democratic, honest, fair general elections in 1999, 2004 and 2014.

Aside from the positive impact, there are the negative impacts of reformation as well. Some elements of the nation infer thet the freedoms of speech and of expression are not constrained by any legislation, hence frequently inducing horizontal and vertical conflicts between and among people. Destructive expressions may be by social media, where hate speeches (Saracen) and hoaxes are spread by certain community groups. Hate speeches are ones detrimental to social order within a commuity, leading to social conflicts in the community. Therefore, hate speeches should be promptly handled in order to prevent social conflicts (Pamungkas, 2016). Likewise, Massaro (2011) suggest that freedoms of speech and of expression do not always result in good speeches. That is, granting freedoms of expression and of speech is not always a good and fair policy. Futhermore, according to Brink (2001), hate speech is an expression of discriminative attitudes intended to insult and stigmatize the victims or others based on race, nationality, gender, sexual orientation, religion, tribe, group or other membership.

The exercises of hate speeches and hoaxes by community groups are made by social media, printed media, and other electronic media. They are generally proliferating particularly during regional general elections, being used as a means of black campaign against those political rivals who are considered as competitor in regional general elections. As a consequence, identity politics with nuances of ethnicity, religion, race and inter-group has developed. If it is left unresolved, it may lead to national disintegration that harms the nation. 
To deal with the hate speeches, Massaro (2001) offers some approaches, namely: a allows hate speech so as to secure individual freedom of expression, b. Supresses hate speech by strict santions, official censures, and even criminal presecution that promote equality, and c. Tries to control hate speech and forbids any abuse of an individual or group based on race, gender, religion, origin, ethnicity, sexual orientation, group, or other characteristics protected. Meanwhile, Syahayani (2005) maintains that anyone has constitutional rights of expression and of speech, but in exercising the rights he or she ought to respect others 'basic rights. It applies to individuals, communities, and institutions including mass media (organizations, government elements, etc), both in real and virtual worlds. One should not only have a right to express his or her freedom but also should be respobsible if the freedom collides against or erodes the freedom of others. Freedom requires a balance of rights and obligation as well.

Responding to the prolifertaion of hate speech in Indonesia that is currently threatening our national integrity, Majelis Ulama Indonesia (Indoneisan council of Religious Scholars) has issued a fatwa (religious decree) Number 24 of 2017 on Law and Guidance of Bermuamalah BY Social Media. Item d point 3 prohibits spreading informasi that contains hoax, ghibah, insult, namimah, disgrace, hate speech, and others of the kind that are inappropriate to disseminate publicly, and point 4 prohibits spreading information to conceal any mistake, to right something wrong, and to wrong something right, developing opinions intended to hide truth and to deceive public. Responding to the same issue, Head of the Indonesian Police (Kapolri) issues aCircular Letter No. Se.06/X/2015 regarding the Handing of Hate Speech. In item $\mathrm{f}$ it is specified that hate speech can be in form of crimes as stipulated in Criminal Code (KUHP) and other criminal provisions outside KUHP, including among others: 1. Insult; 2. Aspersion; 3. Humiliation; 4. Unpleasant acts; 5. Provocation; 6. Agitation; and 7. Spreading of hoax. All of the acts above have any purpose or may impacts discriminative act, violence, homicide, and/or social conflicts. Item $g$ decribes that the purpose of the hate speech as intended is to provoke and trigger hate against individuals and groups in various as distinguished from aspects of: 1. Tribe; 2 . Religion; 3 . Religious sect; 4. Belief/faith; 5. Race; 6. Inter-groups; 7. Colors; 8. Ethnicity; 9. Gender; 10. Difables; and 11. Sexual Orientation.

In attempt to realize national harmonization and integration, each community or group in the nation is required to posses: a. Commitment genuinely grounded in the spirits of togetherness and of being in the same boat, b. Spirit of unity in handling local, regional, and international challenges which is consistently based on common aspirations relating to the Unitary State of Republic of Indonesia, and National character values in societal and national lives.

Meanwhile, to keep integration in national life, the followings should be avoided: a. Thoughts and perceptions among ethnicities, religions, languages, customs, and community groups, where one perceives as being superior or inferior to another, or as being stronger or weaker than another, b. such thoughts and perceptions may give a rise to social envy, leading to social conflicts and eventually putting a risk to national unity, c. Discrepancies of development between regions ought to be avoided because a very fast development in one region while another regions lag far behind may induce social envy, d. Social and economic discrepancies between communities have to be avoided by serious measures of eliminating poverty, and e. Excessive measures of curbing democratization and decentralization processes for reasons of national stability and unity must be avoided (Suhadi \& Sinaga, 2006). 


\subsection{Sosial Vulnerabilities}

The fact that Indonesia's peopleare very pluralistic, with low levels of national awareness, tolerance, harmony, and cooperation, and with high disparities in interregional developments may lead to conflict vulnerabilities. Unless controlled by an appropriate approach, social conflicts may occur and eventually trigger a very massive national disarrangement. Moreover, it may turn into an embryo of national disunity, where each ethnic community prioritizes its own self-interest. In this case, diversities of tribes, religions, races, ethnicities, and groups may deter development, each ethnicity being always prioritizing its group's interests and thus inducing conflicts (Koentjaraningrat, 1990:379).

Religious and ethnic pluralisms of Indonesia's populationare shown by data that a majority of Indonesians, $\pm 87.65 \%$, are Moslems. In terms of ethnicity, Indonesia's population is composed of: Javanese $40 \%$, Sundanese $15 \%$, Chinese $3.73 \%$, and other ethnicities (BPS, 2016). The data shows that Javaneses are majority in Indonesia in terms of both ethnicity and religion. A crucial problem now is that there is an indication that certain ethnic and religious groups still play up their own social identities on a basis of the ethnicity and religion they belong to. If this is practiced by all ethnicities and religious believers it will potentially lead to horizontal conflicts between those different, rivalry groups which are of different group identities (Murniati et al., 2015:5). To make it worse, there are found some indications of the increases in primordial attitudes among different ethnicities, groups, and tribes, particularly in the era of regional autonomy nowadays. The destructive conditions are a threat to both integration and harmony of national life.

Some social vulnerabilities which pose threats to national harmony and integration are, among others: a) pervasive practices among tribes, ethnicities, and races for one to get married toanother for sharing the same religion, tribe, race, and ethnicity, b) Relatively low emphatic attitudes to other ethnic cultural values, c) Lack of behaviors of passing over value social culture, d) The growth of tribal and primordial attitudes in contradictory to assimilatory and integrative efforts, e) Competitions among tribes for political positions and other livelihoods, f) Emergence of negative prejudices among ethnicities that may trigger SARA-related conflicts, g) Disclosure of some indication of increasingly lower social and nationalistic awareness at both national and local scales, h) Increasing social disparity that induces social envy, i) Absence of alternative standard format of ethnic assimilation to apply in Indonesia, and j) Uncertainties of law enforcement and of eradication of collusion, corruption, and nepotism practices. Such social vulnerabilities will, unless dealt with by an appropriate approach, possibly lead to disintegration of the nation or even to be a failed nation. Therefore, some appropriate, comprehensive, holistic, humanity-minded approaches are needed.

\subsection{Approaches to Bringing About Harmony and Integration}

The diversity of Indonesia's people with different backgrounds of social life has various complex dimensions. Therefore, the whole components of the society have to recognize that social lives in such setting should not be seen from a viewpoint of community uniformity. They belong to different communities. Any differences among the communities of tribes, religions, and races in social interactions are not tabooed for ethnic integration, social change, adaptation, acculturation, assimilation, and amalgamation (Horton, 1991:397). That is, diversity of communities is, despite posing social conflict vulnerabilities, not impossible to reinforce integration, and even may lead to harmonious, peaceful, secure life, if well managed (Dahesihsari, 2015; Wahab, 2015). Bringing about national harmony and integration may be realized by different approaches, some of which are described briefly below. 


\section{a. Religious Approach}

The tendency of certain ethnicities and national tribes to profess their own religion is not something destructive in religious life. An open-minded community never blames the religion other communities profess. A statement that a certain tribe mostly professes only a certain religion is a misleading opinion. Thus, ethnic Toba Bataknese ethnic cannot be categorized as the followers of Christianity as a whole, nor ethnic Javanese can be categorized as the followers of Islam as a whole. There are some Moslems in the former and, conversely, there are some Christians in the latter. The same is true for other ethnicities.

The existence of different religious believers in one ethnicity and among ethnicities serves a safety valve in preventing religion-nuanced social conflicts. This is because they still have kinship ties. Though they profess different religions, in adat ceremonies they commonly employ "substitute" cultural objects that are not forbidden by their own religious precepts and acceptable to ethnic communities that profess other religions.

In religious affairs, multiethnic communities should be realistic and rational for them not to be easily provoked by destructive issues. Therefore, it needs to foster attitudes and outlooks that see religious affairs as personal in nature between one and his or her God according to his or her own belief (Wahab, 2015; Ma'mun, 2012).

Those people with religious awareness, who are rational and open-minded, resist strongly religion-related provocations. Such attitude should be encouraged in order for the religion that an ethnicity mostly professes does not turn into a threat against the integration and harmony between communities, but rather to be a glue and unifier between them. In preaching their own religious tenets, the clerks should explain, besides from transcendental values, that God creates diversity of humans for them to help and love one another. In addition, it should be emphasized that between and among different religious believers there should mutual respect, tolerance, peace, and harmonious life (Suryana, 2015).

In deepening religious outlooks, all religious communities may perform "passing over", that is, passing from one faith to another, from one way of life to another, and from "one religion to the tenets of another religion" and then come back to the tenets of their own religion in more creative, innovative, and sympathetic ways. If this is practiced in daily life among religious communities then each of the believers will agree that it is not a taboo to hold a dialogue, to introspect creatively in order to deepen one's faith and strengthen tolerance and cooperation. The essence of religious teachings that are tolerant to other religions'believers is suggested by a principle that for anyone who understand the heart of religion and the religion of heart all religions is the same even though they differ in different communities; conversely, anyone who see that the differences in religions are of highest importance is marginalized (Madjid, 2001).

The importance of interreligious dialogues is to make different religious communities not suspicious against one another; instead, they should share the same perception in building harmony among religious communities and anticipate any forces that intend to manipulate religions in seeking certain goals. Therefore, all religious communities have to thoroughly comprehend the tenets of their own religion in accordance with their holy book. That is, if one wants to learn the tenets of other religion, one should learn it comprehensively, not simply based on the interpretation of a different religion. Thus, the believers may objectively understand the tenets of their own religion without mixing them with the tenets of other religions. 
The constructive attitudes that religious communities should absolutely avoid include, among others: quarrel on religious tenets, fanaticism, fundamentalism, and rejection of both diversity and difference between religious communities. On the other side, an attitude that religious communities should nurture is discarding negative prejudices against other religious communities.

\section{b. Socio-Cultural Approach}

Ethnic diversity is a constructive development potential if it is well managed and developed. Conversely, if poorly managed, it is not impossible that it will lead to disunity. Therefore, all communities should have awareness to develop cooperative attitudes, tolerance, and unity between different communities.

Public life patterns that tend to be materialistic and individualistic resulting from foreign influences cause the lack of cooperation, mutual aid, and communal sense among our communities. Accordingly, all communities should selectively adopt foreign culture elements. If an ethnic community is ignorant, it will be undergoing anomaly and anomie of globalization culture. It may lead, in turn, to a shift in cultural values due to the lack of understanding and attachment to the values of indigenous culture. The lower the attachment of someone to his or her socio-cultural values, the looser his or her attachment to his or her own cultural values.Realizing that the socio-cultural values a multiethnic community possesses are inseparable and undetached from its life, harmony of lives can only be created by building an awareness of multiculturalism.Multiculturalism is an acknowledgement of cultural and ethnic diversity that develops an interest in seeking that minority groups be integrated into the community andthat majority ready to accommodate them by constantly acknowledging the minorities' identity (Kimlycka, 2003:13). This viewpoint gives us a meaning and awareness that ethnic diversity brings with it a consequence that socio-cultural values do vary.

Indonesia's people have not fully understood yet the meaning of slogan Bhineka Tunggal Ika. This is why SARA-related conflicts still frequently occur. Therefore a spirit of plurality, integrity, justice, sincerity, and awareness of creating togetherness for the development of a multicultural community in the pluralities of cultures, ethnicities, and life harmony is needed (Murniati et al., 2015). In social interactions and contacts between ethnicities, all communities should not develop negative prejudice against one another. In social interactions, ethnic and tribal attitudes should be aware of socio-cultural values by cross-cultural and cross-ethnic activities.

Joint, cross-ethnic, and cross-cultural activities performed by always involving the whole community may be in forms of cultural party, folk party, art performance, discussion, and seminar. These activities are intended to preserve cultural elements and also as an enculturation medium for youth generation and to deepen understanding on the uniqueness and diversity of socio-cultural values. All ethnic communities should show no antipathy against other ethnicities' customs and socio-cultural values, in order for a mutual understanding between ethnicities on the socio-cultural values may be enhanced (Ma'mun, 2012).

\section{c. Good and Clean Governance Approach}

Good, clean, and accountable governance is a prerequisite in improving the quality of public services in accordance with the public aspirations. To accomplish the goal, changes in attitudes, behaviors, and working ethos of all public servants, eradication of collusive, corrupt, and nepotism characters, and first-rate services are needed. 
Moreover, to uphold law supremacy based on presumption of innocence, all communities have to be optimistic that a good, clean, transparent government will gradually be realized. Therefore, the whole people should change their attitudes consequently and consistently. Admittedly, in realizing law supremacy which is a requirement for improving the quality of public service, hard work and a sense of missionin all public officers, law enforcers, and communities are needed in practicing cultures of hard work, honesty, law obedience, and rejection of collusion, corruption, and nepotism (KKN). To the purpose, the government should, by its policies, attempt to minimize deviations, be consistent in complying with law, and solve law infringement transparently, honestly, and fairly.

Real enforcement of law supremacy and the indiscriminative eradication of $\mathrm{KKN}$ are the indications of the government's seriousness in enforcing law. Thus, the implementation of law enforcement is like a double-edged sword, which should not be strict only to lower class but slack to upper class. Such policy would increase public trust to public officials and law enforcers, and thus a synergy between the government and people can be realized. In general, the term "policy" used to designate the behavior of an actor (for example an official, a group, as well as a government agency) or a number of actors in a particular area of activity. The term policy is distinguished from the word wisdom meaning wisdom or wisdom. Policy is a general statement of behavior than organization (Purba, 2019).

With all public apparatuses and law enforcers consistently implementing their duties and responsibilities in compliance with legislations, it is expected that good, clean, and accountable governance will gradually be realized, and thus public trust to civil officers and law enforcers will increase.

\section{d. Empowerment of Mass Organization Approach}

In essence, human beings are a social creature who prefers to live in a society and in groups. Humans are social creature, besides from being individual creature, who cannot meet their own livelihood individually without the aid of others. Therefore, to survive, humans have to live together in groups with fellow humans.

The establishment of a community is based on an association of a group of humans who live together, uphold shared values, and inhabit a common area. The community comprise of diverse tribes, ethnicities, and races with different backgrounds. The process of establishing a community group is based on similarities in socio-cultural values, religious systems, blood ties (kinship), and shared interests, needs, and livelihoods. In fulfilling their requirements, all ethnic communities, individually and in groups, would seek to establish a medium of cooperation. The objective of establishing such a social organization is, besides from consolidating life integration and harmony, as a means of enculturation of socio-cultural values.

The importance of mass organizations' roles and positions in creating life harmony and in solving lots of conflicts domestically has been tested and attested thus far. Without mass organizations' roles, security agencies would find it difficult to solve various problems emerging among people. Thus, mass organizations' roles should not be simply ignored. In Indonesia, there are lots of mass organizations, e.g.: Interfaith Communication Forum (FKAUM), Cross-Tribe and Cross-Religion Communication Forum (FORKALA), and other Non-Governmental Organizations (NGOs). These mass organizations have great potentials to be engaged in assuring security and in supplying inputs and supervision of development. 


\section{e. Politic and Security Approach}

Reformation era brings about very drastic, fundamental changes in all national life aspects, e.g., institutionalizations of direct general elections and a multiparty system. Citizens directly vote the memberships of their regional parliament (DPRD), parliament (DPR), and senator (DPD), as well as regional government heads and president/vice president, according to the applicable legislations. A major problem still faced with after \pm 19 years of reformation is that there are still allegedly abuses of power by some legislative, executive, and judicative officers as indicated by the increasing numbers of those individual officers who are implicated in KKN practices. Therefore, it is safe to say that, in Indonesia, corruptions have turned into a culture and are committed collectively. If such practices are constantly going on, a crisis of trust to legislative, executive, and judicative institutions willrise. And if it is left uncorrected, chaos and even violence may occur, because such behaviors deviate from the spirit of reformation.

As a consequence of the reformation movement, military (TNI) and police (POLRI) were reorganized by the enactment of Law Number 3 of 2002 on State Defense, Law of 2002 on Republic of Indonesia Police, and Law Number 34 of 2004 on Indonesian National Military. In the three laws, TNI and POLRI are separated institutionally, but in the duties of national security the two institutions develop coordination in performing their own Main Duties and Functions (TUPOKSI). The main duties of TNI as stipulated in article 7 paragraphs 1 and 2, are to keep national sovereignty, to defend the territory of the Republic of Indonesia Unitary State based on Pancasila and the 1945 Constitution, and to secure the unity of nation and state. The main duties are implemented by: a) Military operations and wars, b) Military operations other than wars (Law No. 34 of 2007, Article 7 paragraphs 1-2). Meanwhile, according to the Article 13 of Law No. 2 of 2002 on Republic of Indonesia Police, the main duties of Republic of Indonesia Police are: a) To keep public security and order, b) To Enforce law, c) To provide protection and services to general public (Law no. 2 of 2002, Article 13).

In implementing their duties and functions, both TNI and POLRI should, as agencies responsible for state and public security that are professional in solving various problems (social conflicts) and other security threats, prefer a persuasive approach. In addition, they should minimize procedural errors in dealing with cases so as to avoid infringing human rights. If it can be accomplished well, senses of being secure, comfortable, and peaceful will be grown among general public, and thus integration and harmony of lives can be achieved as expected.

\section{Conclusion}

Harmony and integration of our multicultural and multiethnic communities are of high importance to realize in securing the unity of Indonesia as mandated by both Pancasila and the 1945 Constitution. However, in the process there are still various challenges and threats encountered in forms of social vulnerabilities, SARA-related sosial conflicts, hate speech, hoax, development discrepancies, radicalism movements, and separatism movements by some elements of the nation.

To overcome the problems, the government and the whole national elements should jointly deal with the destructive forces through comprehensive and holistic approaches. The approaches pursued in realizing the harmony and integrationmay be: religious, socio-cultural, good and clean governance, mass organization, politic, security, and other approaches. Through these approaches, it is expected that all societal elements may work together in synergic ways so as to achieve security and harmonious, peaceful lives, and thus national integration can be realized as aspired. 


\section{References}

Agustian, Murniati. 2015. Multicultural Approach. Jakarta: Atma Jay Press

Barth, Prederick, 1982. Ethnic Group and Its Limits. Jakarta UI Press.

BPS. 2017. Indonesia dalam angka. Jakarta: Biro Pusat Statistik

BPS. 2018. Indonesia dalam Angka. Jakarta: Biro Pusat Satatistik

Brink, O. David. 2001. Millian Principles, Freedom of Expression and Hate Speech. In Journal Legal Theory. No. 7. pp.119-157

Bungin, Burhan. 2008. Penelitian Kualitatif. Jakarta: Kencana

Creswell. 2014. Research Design: Pendektana Kualitatif, Kuantitatif dan Mixed. (Diterjemahkan:Ahmad Pawai). Jakarta: Pustaka Pelajar 2015. Penelitian Kualitatif dan Desain Riset, Memilih Diantara Lima Pendekatan. (Diterjemahkan: Ahmad Lintang). Jakarta: Pustaka Pelajar.

Fichers, Cluade. 1980. Theories of Urbanise. In: George Gmelch \& Walter P. Zenner (ed) Urban Life Reading in Urban Anthropology. New York: St. Marthins.

George, Gemelack, L. Zenner P, Walter. 1980. Urban Life Reading in Urban Anthropology, New York: St. Marthins Press

Hasbullah, et al (2018). Communication Pattern of Wilayatul Hisbah, Lhokseumawe City in Implementing Amar Makruf Nahi Mungkar. Budapest International Research and Critics Institute-Journal (BIRCI-Journal); 194-205.

Horton. 1991. Sosiologi. Jakarta: Rajawali Press

Khalil, M., et al (2019). Implementation of Marriage in the Period of Armed Conflict in Aceh.

Britain International of Humanties and Social Sciences (BIoHS) Journal; 16-25.

Kyulicka, Willy. 2003. Kewarganegaraan Multikultural. Jakarta: Gramedia

Koentjaraningrat. 1977. Metode Penelitian Masyarakat. Jakarta: Gramedia 1990. Manusia dan Kebudayaan. Jakarta: Gramedia

Madjid, Nurcholish (Ed). 2001. Passing Over (Melintas Batasa Agama). Jakarta: Gramedia

Ma'mun. H. 2012. Potret Hubungan Etis dan Agama di Jakarta. Jakarta: Referensi

Massaro, MT. Equality and Freedom of Expression. In Jurnal The Hate Speech Dilemma. Vol. 32. Issue 2. pp.211-265

Pamungkas, ASA. 2016. Perspektif Hak Azasi Manusia pada Surat Edaran Kapolri Nomor SE/06/X/2016 dalam penanganan penyebaran ujaran kebencian melalui media sosial. Yogyakarta: Fakultas Hukum Universitas Atmajaya

Purba, N.A.Y., et al. (2019). The Social and Public Health Impacts that Occurred in Rantau Utara Subdistrict after the Publication of the Labuhanbatu District Regulations No.10 of 2011 About the Swallow Bird Tax, Indonesia. Britain International of Humanties and Social Sciences (BIoHS) Journal; 64-73.

Rusdiana, A and Suryana Yaya. 2015. Pendidikan Multikultur. Bandung: Pustaka Setia

Sartono Kartodirdjo. 1993. Integral Nasional: Yogyakarta, UGM

Sitohang, Veryanto, 2011. Lahir untuk Merawat Pluralism. Medan, Hivos

. 2012. Sumatera Utara Rawan Untuk Kemerdekaan Beragama dan Berkeyakinan Medan: Hivos

Suhadi, Idup \& Sinaga AM. 2006. Wawasan Kebangsaan Dalam Rangka Negara Kesatuan Republik Indonesia. Jakarta: LAN Press

Syahayani, 2015. Hate Speech dalam Ruang Kebebasan Berpendapat. Dalam Jurnal The Indonesia Institute. Vol. IX. No. 12. hal 2-5

Wahab, Jamit A. 2015. Harmoni di Negeri Seribu Agama. Jakarta: PT. Elex Media Komputindo. 
Wijaya, Yahya. 2015. Studi Lintas Agama Mendamaikan Teologi dan Studi Agama: Dalam Mengelola Keragaman di Indonesia. Ed. Bernard Adeney Risakota. Yogyakarta: ICRS Mizan

Zed, Mustika. 2008. Metode Penelitian Kepustakaan. Jakarta: Yayasan Obor.

Fatwa Majelis Ulama Indonesia Nomor 24 Tahun 2017. Tentang Hukum dan Pedoman Bermuamalah Media Sosial, 13 Mei 2017. Jakarta.

Surat Edaran Kapolri Nomor SE/06/X/2015 tentang Penanganan Ujaran Kebencian (Hate Speech), butir f dan $g$.

Undang-undang Republik Indonesia nomor 2 tahun 2002 a). Tentang Kepolisian Negara Republik Indonesia, Jakarta: Sekretariat Negara.

Undang-undang Republik Indonesia nonor 3 tahun 2002 b). Tentang Pertahanan Negara. Jakarta: Sekretariat Negara.

Undang-undang Republik Indonesia nomor 34 tahun 2004 Tentang Tentara Nasional Indonesia, Jakarta: Sekretariat Negara. 